\title{
Practical Applications of Fish Oil ( $\Omega-3$ Fatty Acids) in Primary Care
}

Robert $\mathrm{Ob}, \mathrm{MD}$

Background: Fish oil ( $\Omega$-3 fatty acids) has been studied for more than 30 years. However, recent concerns of mercury and environmental toxins have clouded fish oil's potential clinical benefits. This article aims to review practical, evidence-based applications of fish oil for the primary care physician.

Methods: PubMed search using key words 'fish oil,' 'docosahexaenoic,' and 'eicosapentaenoic' in title/abstract. Limited to human clinical trials. Articles were further scanned for relevant sources.

Results: For secondary prevention of cardiovascular disease, $1 \mathrm{~g}$ of fish oil has shown to reduce overall and cardiovascular mortality, myocardial infarction, and sudden cardiac death. Higher doses may be used for its potent triglyceride-lowering effects and for patients with rheumatoid arthritis to reduce nonsteroidal anti-inflammatory use. $\Omega-3$ fatty acid supplementation of infant formula has shown benefit in infant neural growth and development. With the potential health benefits of fish, women of childbearing age should be encouraged to eat 1 to 2 low-mercury fish meals per week.

Conclusions: Fish oil has numerous practical applications for the primary care physician. Understanding the diverse clinical research of $\Omega-3$ fatty acids and fish oil is important in determining its role in primary care practices. ( $\mathrm{J}$ Am Board Fam Pract 2005;18:28 -36.)

More than 30 years ago, Danish researchers hypothesized that lower rates of heart disease of Greenland Eskimos were associated with higher consumption of whale, seal, and fish. ${ }^{1,2}$ Since then, from research unraveling the mechanism of $\Omega-3$ fatty acids, to clinical trials in cardiovascular disease, treatments of hyperlipidemia, rheumatoid arthritis, and the prevention of preterm labor, there have been more than 7000 reports-including nearly 900 human clinical trials on the study of fish oil and $\Omega-3$ fatty acids. ${ }^{3,4}$ However, recent concerns regarding mercury and other environmental toxins have clouded the waters of fish oil research and its potential health benefits. This article will discuss the evidence behind fish oil-emphasizing current, practical information for conditions family physicians can effectively impact today.

Submitted, revised, 26 July 2004.

From the Department of Family Medicine, MCHJ-FP, Madigan Army Medical Center, Ft. Lewis, Washington. Address correspondence to: Robert Oh, MCHJ-FP, Madigan Army Medical Center, Ft. Lewis, WA 98431 (e-mail: roboh98@earthlink.net).

The opinions or assertions contained herein are the private views of the author and are not to be construed as official or as reflecting the views of the Department of Defense.

\section{Methods}

Medline and Cochrane database search using the key words "fish oil" or "docosahexaenoic" or "eicosapentaenoic." These were combined with the keywords "cardiovascular disease," "myocardial infarction," "hypertriglyceridemia," "pregnancy," "rheumatoid arthritis," or "infants." Search was further limited to humans, clinical trials. References from key articles were also scanned for relevant sources.

\section{Results and Discussion \\ Mechanism of Action}

There are 2 classes of essential fatty acids, the $\Omega-6$ and $\Omega-3$ fatty acids (FA). $\Omega-3$ FA, found primarily in fatty fish with high oil content, consists of both eicosapentaenoic acid (EPA) and docosahexaenoic acid (DHA). Research has shown increasing evidence for anti-inflammatory, antithrombotic, antiarrhythmic and antiatherogenic effects of fish oil. ${ }^{5}$ Fish oil is the most significant source of dietary $\Omega-3$ FA. The terms will be used interchangeably.

Arachidonic acid, an $\Omega-6 \mathrm{FA}$, is converted into inflammatory prostaglandins and leukotrienes via the enzymes cyclooxygenase and lipoxygenase, respectively (Figure 1). Increased intake of $\Omega-3 \mathrm{FA}$ reduces incorporation of arachidonic acid into cell 


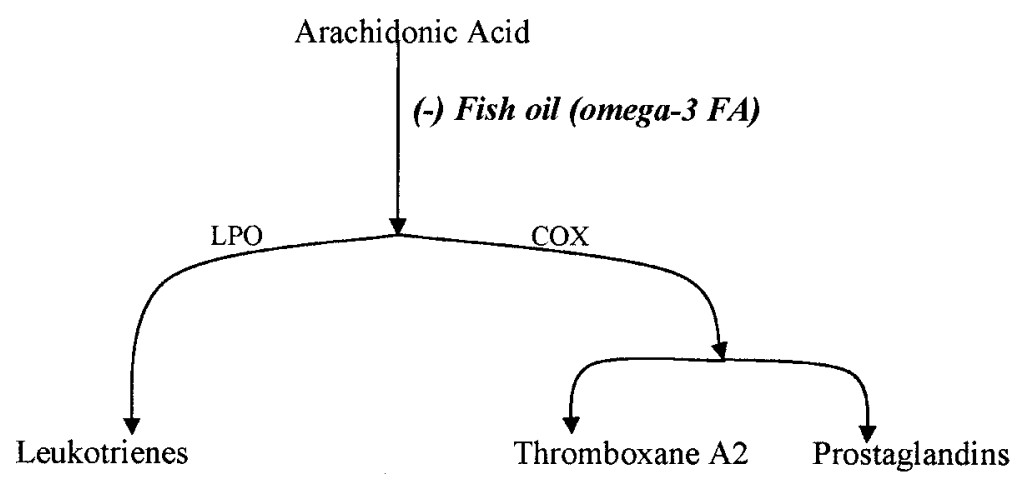

Figure 1. Arachidonic acid is converted to leukotrienes by the enzyme lipoxygenase (LPO) and to thromboxane A2 and prostaglandins by the enzyme cyclooxygenase (COX). $\Omega-3$ fatty acids, in essence, reduce the breakdown of arachidonic acids.

membranes, thereby promoting a net anti-inflammatory response. Indeed, fish oil has been shown to significantly decrease potent inflammatory markers, including leukotrienes, prostaglandins, interleukins, and tumor necrosis factor. ${ }^{6,7}$ The inhibition of arachidonic acid by $\Omega-3 \mathrm{FA}$ also produces a potential antithrombotic effect by decreasing production of thromboxane A2. Membrane stabilization in cardiac tissue by $\Omega-3 \mathrm{FA}$ confers potential antiarrhythmic effects, ${ }^{8}$ whereas triglyceride-lowering effects are caused by the reduction and secretion of very low density lipoprotein particles from the liver. ${ }^{5}$ With its unique and varied mechanism of actions, the potential uses of fish oil have been studied in various clinical situations.

\section{Clinical Uses}

\section{Cardiovascular Disease}

The benefits of fish oil in cardiovascular disease provide the strongest and most compelling evidence favoring its use in practice. Numerous observational studies have shown that $\Omega-3$ FA enriched diets are associated with reduction of cardiovascular mortality, myocardial infarction, and sudden death. Higher fish intake was associated with decreased incidence of coronary artery disease and cardiovascular mortality in several prospective cohort studies. $^{9-11}$ Another large prospective cohort study reported a marked reduction in sudden cardiac death associated with dietary fish intake. ${ }^{12,13}$ Putting it in perspective, a minimum of one fish meal a week was associated with a $52 \%$ reduction in sudden cardiac death. Some observational trials do not show a beneficial relationship for fish intake. This may be related to differences in background cardiovascular risk, fish intake, or lifestyle behaviors of study populations and study definitions of sudden death and fish intake. ${ }^{14}$ Although the intake of fish oil in these studies was not sufficient to produce a marked anti-inflammatory or triglyceride-lowering effect, both antiarrhythmic properties and membrane stabilization of cardiac tissue by fish oils has been proposed as its mechanism of action. ${ }^{8}$

Randomized clinical trials add to the growing evidence-especially for secondary prevention of cardiovascular disease. A randomized placebo-controlled trial showed that supplementing patients with recent history of a myocardial infarction (MI) with $1.8 \mathrm{~g}$ of fish oil for 1 year decreased total cardiac events by $29 \%$ [number needed to treat $(\mathrm{NNT})=10$ for 1 year; $P<.05]$. Both total cardiac deaths and nonfatal MI were also reduced by $48 \%$ $(\mathrm{NNT}=8.1$ for 1 year; $P<.01$ and $\mathrm{NNT}=9.8$ for 1 year; $P<.01$; respectively $)^{15}$ [level of evidence-1 (LOE)]. The Diet and Reinfarction Trial (DART) ${ }^{16}$ randomized 2033 men with myocardial infarction into different dietary groups. Men randomized to fatty fish diet had a $29 \%$ reduction in the 2-year all-cause mortality compared with those who did not receive this advice (NNT $=28$ for 2 years; $P<.05)$. Most of the benefits resulted from the reduction of cardiovascular deaths $(\mathrm{NNT}=27$ for 2 years; $P<.01)(\mathrm{LOE}-1)$. The GISSI ${ }^{17}$ trial randomized 11,324 Italian men who had suffered a myocardial infarction within 3 months. Compared with the control group, patients supplemented with fish oil $850 \mathrm{mg}$ showed a $15 \%$ reduction in the primary endpoints (death, nonfatal myocardial infarction and stroke) after 3.5 years $(\mathrm{NNT}=48$ for 


\begin{tabular}{lc}
\hline Patient Population & Recommendations \\
\hline Patients WITHOUT documented coronary heart disease & $\begin{array}{c}\text { Eat a variety of (preferably fatty) fish at least twice a week. } \\
\text { Include oils and foods rich in } \alpha \text {-linolenic acid (flaxseed, canola, } \\
\text { and soybean oils; flaxseed and walnuts) } \\
\text { Consume approximately } 1 \mathrm{~g} \text { of EPA+DHA per day, preferably } \\
\text { Patients WITH documented coronary heart disease }\end{array}$ \\
$\begin{array}{c}\text { from fatty fish. EPA+DHA supplements could be considered in } \\
\text { consultation with the physician. }\end{array}$ \\
$\begin{array}{c}2-4 \mathrm{~g} \text { of EPA }+ \text { DHA per day provided as capsules under a } \\
\text { physician's care. }\end{array}$ \\
\hline
\end{tabular}

${ }^{*}$ http://www.americanheart.org/presenter.jhtml?identifier $=4632$

3.5 years; $P=.008)(\mathrm{LOE}-1)$. It is striking that most of the benefit was derived from a $30 \%$ reduction in cardiac mortality and a $45 \%$ reduction in sudden death. Mortality reduction was significant in just 3 months of fish oil therapy - even in light of optimal pharmacologic therapy with antiplatelet agents, angiotensin inhibitors, and lipid lowering therapy. ${ }^{18}$

Finally, a meta-analysis ${ }^{19}$ and a recent systematic review $^{20}$ launched by the Agency for Health Care Research and Quality (AHRQ), found favorable effects of fish oil on cardiovascular and overall mortality. With this mounting evidence, the American Heart Association, ${ }^{14}$ recommends $1 \mathrm{~g}$ of fish oils in all patients with documented coronary artery disease via diet or through supplementation after consultation with their physician [strength of recommendation (SOR)-A] (Table 1).

\section{Hypertriglyceridemia}

High triglycerides have been recognized as an independent risk factor for coronary artery disease. The Third Report of the Expert Panel on Detection, Evaluation, and Treatment of High Blood Cholesterol in Adults (ATP III), ${ }^{21}$ recommends treating hypertriglyceridemia more aggressively. However, medications to treat hypertriglyceridemia (such as fibric acid derivatives and niacin) are limited and can have serious side effects. Even with medications, hypertriglyceridemia can be difficult to treat without using a combination of drugs.

A review of over 70 clinical trials ${ }^{22}$ and a recent systematic review by the $\mathrm{AHRQ}^{23}$ have demonstrated the consistent and potent triglyceride lowering effects of fish oil supplementation. In an early trial, mean triglycerides were reduced $79 \%$ (from 1432 to $282 \mathrm{mg} / \mathrm{dL})$ using $20 \mathrm{~g}$ of fish oil. $(P<$
.01). ${ }^{24}$ More recently, in patients with severe hypertriglyceridemia $($ mean $=919 \mathrm{mg} / \mathrm{dL}), 3.4 \mathrm{~g}$ of fish oil showed a triglyceride reduction $45 \%$ compared with controls $(P<.0001){ }^{25}$

Although studies are limited, combination therapy with a statin seems to be safe and the results additive. Adding $3 \mathrm{~g}$ of fish oil to $40 \mathrm{mg}$ of pravastatin reduced triglycerides an additional $33 \%{ }^{26}$ Another study, combining $3.4 \mathrm{~g}$ of fish oil daily in patients with persistent hypertriglyceridemia on 10 to $40 \mathrm{mg}$ simvastatin, showed additional reduction in triglycerides by $20 \%$ to $30 \%$, without serious adverse effects. ${ }^{27}$ Another trial, however, using 10 $\mathrm{mg}$ of atorvastatin and $1.7 \mathrm{~g}$ of fish oil, did not show significant difference from baseline. This trial may have been limited by their lower dosage of fish oil and the higher background fish consumption by the patients. ${ }^{28}$

Overall, there is a dose-dependent lowering of triglycerides with higher fish oil supplementation. Although on average, low density lipoprotein (LDL) cholesterol rose $10 \mathrm{mg} / \mathrm{dL}$ and high-density lipoprotein $3 \mathrm{mg} / \mathrm{dL}$, these were nonsignificant. ${ }^{23}$ There were no significant changes in total cholesterol. Use of 2 to $4 \mathrm{~g}$ of fish oil, which lowers triglycerides by $20 \%$ to $50 \%$, may be recommended for patients with mild or persistent hypertriglyceridemia to reach ATP III goals (SOR-A) (Table 1). ${ }^{14,21}$

\section{Rheumatoid Arthritis}

In patients with rheumatoid arthritis (RA), over 15 clinical trials and 2 meta-analyses favor the use of fish oil. ${ }^{29,30}$ Fish oil supplementation consistently shows modest clinical improvement and reduction of nonsteroidal anti-inflammatory drug (NSAID) use in randomized clinical trials. One trial compared approximately $2.8 \mathrm{~g}$ of fish oil versus placebo 
Table 2. Clinical Uses and Recommendations

\begin{tabular}{|c|c|c|c|}
\hline Clinical Use & Dosage & Comments & Strength of Recommendation \\
\hline $\begin{array}{l}\text { Secondary prevention of } \\
\text { cardiovascular disease }\end{array}$ & $1-2 \mathrm{~g} /$ day & $\begin{array}{l}\text { May encourage dietary intake, or } \\
\text { fish oil supplementation }\end{array}$ & $\mathrm{A}^{19,20}$ \\
\hline Hypertriglyceridemia & Initial $2-4 \mathrm{~g}$; up to $12 \mathrm{~g}$ & $\begin{array}{l}\text { For doses greater than } 3 \mathrm{~g} \text {, } \\
\text { consider monitoring for } \\
\text { bleeding side effects, LDL, and } \\
\text { glycemic response }\end{array}$ & $\mathrm{A}^{23}$ \\
\hline Rheumatoid arthritis & $\begin{array}{l}2.6-6 \mathrm{~g} \text { may initiate at } 90 \mathrm{mg} / \mathrm{kg} \text {; } \\
\text { maintenance dose } 45 \mathrm{mg} / \mathrm{kg}\end{array}$ & $\begin{array}{l}\text { May take } 8-12 \text { weeks for clinical } \\
\text { response; consider tapering } \\
\text { NSAIDs; compliance may be } \\
\text { an issue }\end{array}$ & $\mathrm{A}^{29,30}$ \\
\hline $\begin{array}{l}\text { Infants (not breast- } \\
\text { feeding) }\end{array}$ & $0.35 \%$ of dietary fat as DHA & $\begin{array}{l}\text { Consider } \Omega-3 \text { and } \Omega-6 \text { enriched } \\
\text { infant formula }\end{array}$ & $\mathrm{B}^{42,43}$ \\
\hline $\begin{array}{l}\text { Women (pregnant and } \\
\text { of childbearing age) }\end{array}$ & $\begin{array}{l}2 \text { fatty fish meals a week (up to } \\
12 \mathrm{oz} \text { ) }\end{array}$ & $\begin{array}{l}\text { Avoid shark, tile fish, king } \\
\text { mackerel, swordfish. Limit } \\
\text { albacore tuna to } 6 \mathrm{oz} \text { per week. }\end{array}$ & $C^{47,48,66}$ \\
\hline
\end{tabular}

in 64 patients with stable RA. In 3 months, the fish oil group showed significant reduction of NSAID use compared with placebo. This effect peaked at 12 months and was not associated with any clinical deterioration (LOE-2). ${ }^{31}$ A double-blind placebocontrolled trial showed that fish oil supplementation of $130 \mathrm{mg} / \mathrm{kg} /$ day decreased the number of tender joints, duration of morning stiffness, pain, and global arthritis activity versus placebo (LOE-2). ${ }^{32}$

Reduction of tumor necrosis factor, interleukin levels, and other anti-inflammatory mediators has been hypothesized as the main effect of $\Omega-3 \mathrm{FA}$ in RA. However, others recognize the importance and synergistic effects of a higher intake of $\Omega-3 \mathrm{FA}$ in conjunction with lower dietary intake of $\Omega-6 \mathrm{FA}$. A double-blind placebo controlled trial using lower doses of fish oil ( $40 \mathrm{mg} / \mathrm{kg}$; average, $2.3 \mathrm{~g})$ in a background of low dietary $\Omega-6$ showed clinical improvement compared with placebo over 15 weeks $(P<.02)(\mathrm{LOE}-2) .{ }^{33}$ Clinical improvements were similar to studies using higher doses. Another recent randomized controlled trial showed clinical benefits, reduction of NSAID, and corticosteroid use with low-dose fish oil supplementation $(30 \mathrm{mg} /$ $\mathrm{kg}$; average, $2 \mathrm{~g}$ ) in patients with diets low in $\Omega-6$ FA. ${ }^{34}$ Effects were significant at 3 months and peaked at 6 to 8 months (LOE-1).

For the family physician, although fish oil supplementation may benefit clinical symptoms of RA, its potential to reduce or even eliminate NSAID use $^{35}$ may be the most useful in clinical practice. NSAIDs, although highly effective for pain control, has serious side effects that often limits its use. Overall, doses of 2.6 to $6 \mathrm{~g}$ (or weight-based) of fish oil given for a minimum of 8 to 12 weeks is optimal (SOR-A) (Table 2). ${ }^{32,36}$

\section{Mothers and Infants}

$\Omega-3 \mathrm{FA}$ use in pregnancy has shown promise in prolonging gestation and the prevention of preterm labor. ${ }^{37}$ A randomized double-blind controlled trial showed that supplementation with eggs enriched with $133 \mathrm{mg}$ of DHA prolonged gestation by 6 days compared with women given regular eggs $(P<$ .01). ${ }^{38}$ Looking at women at high risk for preterm delivery, a multicenter study supported the use of fish oil in prolonging gestation. ${ }^{39}$ Women supplemented with $2.7 \mathrm{~g}$ of fish oil showed significantly reduced preterm delivery rates, increased mean birth weight by $209 \mathrm{~g}$, and increased duration of pregnancy by 8.5 days compared with the control group (LOE-1). Fish oil's inhibition of arachidonic acid and its subsequent reduction of prostaglandins have been thought to be a potential mechanism of action.

In 2002, the Food and Drug Administration (FDA) approved supplementation of both $\Omega-3$ and $\Omega-6 \mathrm{FA}$ in infant formula. Both are potentially important in fetal and infant neural development, in that DHA and arachidonic acid have been shown to be incorporated into brain and retinal cell membranes-particularly during the third trimester and early infant life. In both preterm and term infants, evidence consistently shows benefit of visual improvement at 4 months compared with infants fed nonsupplemented formula. ${ }^{40,41}$ Systematic analysis and meta-analysis have shown that higher DHA content of formula is significantly related to improved visual acuity (LOE-1). ${ }^{42,43}$ However, bene- 
fit beyond 4 months is controversial. One recently completed trial showed visual improvement at 12 months in term infants given formula supplemented with $\Omega-3$ FA compared with nonsupplemented formula. ${ }^{44}$ Another study showed sustained increase in intelligence at 4 years of age in children whose mothers were supplemented with fish oil from 18 weeks of pregnancy to 3 months postpartum (LOE-2). ${ }^{45}$

It is important to emphasize that breast-fed infants have outperformed infants fed $\Omega-3 / \Omega-6 \mathrm{FA}$ enriched formula in visual acuity measures. Although increasing dietary intake of fatty fish during the antepartum or breast-feeding period is a potentially attractive alternative to fish oil supplementation, it is unclear how much dietary $\Omega-3 \mathrm{FA}$ intake is essential to maintain the benefit of DHA in breast milk. ${ }^{46}$ Concerns of mercury content in fish also cloud its potential health benefits. ${ }^{47}$

With fish oils' potential benefits in reduction of preterm labor, and improved neural and retinal growth for infants, it is prudent to recommend up to 2 low-mercury fish meals a week for women of childbearing age (SOR-C). ${ }^{48}$ For infants, whereas breast milk continues to be superior over any formula, $\Omega-3$ FA enriched formula should be considered in mothers who are not breast-feeding or have contraindications to breast-feeding. ${ }^{49}$ It may be especially beneficial for preterm infants (SOR-B).

\section{Other Conditions}

With its potential anti-inflammatory actions and membrane stabilization properties, fish oil supplementation has been studied in a wide spectrum of conditions. Studies in inflammatory bowel disease, ${ }^{30,50-52}$ asthma, ${ }^{53,54}$ atopic dermatitis, ${ }^{55}$ psoriasis, ${ }^{56,57}$ renal disease, ${ }^{30,58,59}$ and psychiatric illnesses $^{60,61}$ are either inconsistent or the studies are limited. Studies in neurologic disorders such as ischemic stroke ${ }^{62,63}$ and Alzheimer disease ${ }^{64}$ are beginning to be explored.

\section{Safety Profile}

\section{Environmental Concerns}

Concerns about mercury contamination and other environmental pollutants of fish have recently emerged. ${ }^{4765}$ The FDA and the Environmental Protection Agency (EPA) jointly released an updated consumer advisory on fish intake in March 2004. ${ }^{47}$ Pregnant women (including women planning to conceive), nursing mothers, and children should avoid eating fish high in mercury—shark, king mackerel, swordfish, and tile fish. More significantly, this consumer advisory highlighted the importance of dietary fish. Women should eat 2 meals per week (up to $12 \mathrm{oz}$ ) of low-risk fish for its potential benefits in heart health and childhood growth and development. Fish should not be eliminated from the diet. Similar recommendations were recently issued from the United Kingdom's Food Standards Agency. ${ }^{66}$

For men and those with known cardiovascular disease, physicians must be aware of the risks and benefits of $\Omega-3$ FA to appropriately discuss any recommendations of fish intake or supplementation with their patients. Overall benefits of $\Omega-3 \mathrm{FA}$ in secondary prevention of cardiovascular disease far outweigh any small potential risk for cancer and should not prevent the recommendation of fish oil supplementation for patients at-risk. EPA recommendations are based on the amount of fish intake necessary to raise risk of cancer by 1 case per $100,000 .{ }^{67}$ The reduction of all-cause mortality of fish oil (NNT $=28$ to 48 ) in secondary prevention of cardiovascular disease is similar to the landmark $4 \mathrm{~S}(\mathrm{NNT}=30$ for 5.4 years $),{ }^{68}$ and CARE $(\mathrm{NNT}=30 \text { for } 5 \text { years })^{69}$ trials of statin drugs. Although concerns regarding mercury in fish attenuating its cardiovascular benefits are debatable, ${ }^{70,71}$ it would be reasonable for patients to avoid those fish high in mercury.

\section{Side Effects}

Beyond the common and benign "fishy taste," increases in LDL levels, bleeding times, and a worsening glycemic profile in diabetics have all been raised as safety concerns of $\Omega-3$ FA. Despite these concerns, $\Omega-3$ FA is remarkably safe. ${ }^{72}$ LDL levels rose on average $10 \mathrm{mg} / \mathrm{dL}$, but overall range was inconsistent and has no appreciable effects and may be caused by abnormally suppressed LDL levels. ${ }^{23-25}$ Although early studies raised concerns of a potential for clinical bleeding with high fish oil doses, use of $16 \mathrm{~g}$ of fish oil was clinically insignificant. ${ }^{73}$ Finally, systematic reviews noted no significant difference in fasting glucose levels or glycemic control in patients with diabetes who received fishoil supplements. ${ }^{30,74}$ In patients taking doses higher than $3 \mathrm{~g} /$ day, clinicians may consider monitoring for clinical bleeding and both LDL and glycemic response. 
Table 3. $\Omega$-3 Content in Fish (Cooked, Dry Heat)*

\begin{tabular}{lc}
\hline Fish & $\begin{array}{c}\text { EPA \& DHA† } \\
\text { (mg per 100 g of } \\
\text { edible fish; } \\
\sim 3-4 \text { oz.) }\end{array}$ \\
\hline Herring $^{\ddagger}$ & 1700 \\
Salmon $^{\S}$ & 1600 \\
Mackerel $^{\|}$ & 1400 \\
Flounder $^{\text {Halibut }}{ }^{\text {II }}$ & 500 \\
Tuna** $^{*}$ & 500 \\
Bluefin $_{\text {Canned white }}$ & 300 \\
Canned light & 1500 \\
Cod & 900 \\
Catfish & 300 \\
Haddock & 200 \\
\hline
\end{tabular}

* Approximated to nearest $100 \mathrm{mg}$ (http://www.nal.usda.gov/ fnic/foodcomp/index.html).

${ }^{\dagger} \mathrm{EPA}$ and DHA; EPA=20:5 $\Omega-3 ; \mathrm{DHA}=22: 6 \Omega-3$.

‡ Average; Atlantic and Pacific.

$\$$ Average; Atlantic (wild and farmed), Chinook, pink, coho.

"Average; Atlantic, Jack; Pacific, Spanish.

"I Greenland halibut, $1100 \mathrm{mg}$.

** Skipjack/yellowfin, $300 \mathrm{mg}$.

\section{Dosing, Diet and Formulation}

A recent international working group convened by the National Institutes of Health recognized the dietary importance and potential essentiality of $\Omega-3$ FA. ${ }^{49}$ Adequate intake of $650 \mathrm{mg} /$ day of foods rich in $\Omega$-3 FA was recommended. The American Heart Association (AHA) issued similar guidance, advocating $1 \mathrm{~g}$ of $\Omega-3$ enriched foods daily. However, consistent supplementation may be difficult to maintain through dietary intake because of differences and awareness of $\Omega-3$ FA content in different species of fish and food preparation techniques (Table 3).

Fish oil supplements provide the most consistent way of supplying higher doses of $\Omega-3$ FA. Supplementation can be considered as an alternative to dietary intake for persons who are averse to a fishenriched diet and may also be lower in mercury content and other environmental pollutants. ${ }^{75}$ Most preparations provide approximately $300 \mathrm{mg}$ of total $\Omega-3$ FA, divided between EPA and DHA. Dose requirements greater than $3 \mathrm{~g}$ could potentially require more than 10 capsules per day. However, some highly concentrated versions provide up to $850 \mathrm{mg}$. Because the FDA does not regulate supplements, consumers are cautioned to buy from reputable and reliable brands. United States Pharmacopeia (USP) is an independent, nonprofit organization that verifies manufacturing, quality, and purity claims of supplements for supplement manufacturers who wish to participate. Those supplements branded as USP verified may improve its reliability and safety. Other companies guarantee purity content of their supplements (Table 4).

\section{Conclusion}

Fish saves lives, and physicians must recognize this potential life-saving treatment choice in patients with cardiovascular disease. In addition, family

Table 4. Components of Selected Fish Oil Products

\begin{tabular}{|c|c|c|c|c|}
\hline Brand & $\begin{array}{c}\text { Amount of } \\
\text { EPA \& DHA } \\
\text { (mg per capsule) }\end{array}$ & $\begin{array}{c}\text { Cost }^{*} \\
(\$)\end{array}$ & Number of capsules/day & Web Site \\
\hline GNC Fish body oil & $180 / 120$ & 6.00 & $3-4$ & http://www.drugstore.com \\
\hline Natrol Omega-3 complex & $180 / 120$ & 6.00 & $3-4$ & http://www.drugstore.com \\
\hline Twinlab Omega-3 & $234 / 125$ & 15.00 & 3 & http://www.drugstore.com \\
\hline Mega Twin $\mathrm{EPA}^{\dagger}$ & $600 / 240$ & 15.00 & $1-2$ & http://www.drugstore.com \\
\hline OmegaRx $^{\dagger}$ & $400 / 200$ & 25.00 & 2 & $\begin{array}{l}\text { http://www.zonenetonline.com/ } \\
\text { fishoil_detail.asp?realname = }\end{array}$ \\
\hline Ultimate Omega $^{\dagger}$ & $350 / 250$ & 26.95 & 2 & $\begin{array}{l}\text { https://www.nordicnaturals.com/ } \\
\text { direct/prodsummary.asp?ID = } 30\end{array}$ \\
\hline TriOmega $^{\dagger}$ & 500 (total) & 20.00 & 2 & http://www.triomega.com \\
\hline Kirkland Fish Oil ${ }^{\ddagger}$ & $180 / 120$ & 5.00 & $3-4$ & http://www.costco.com \\
\hline Nature Made Fish Oil ${ }^{\ddagger}$ & $216 / 144$ & 7.00 & $3-4$ & http://www.drugstore.com \\
\hline
\end{tabular}

* 1 -month supply, supplying $1 \mathrm{~g}$ of EPA/DHA.

${ }^{\dagger}$ Pharmaceutical grade or makes claim regarding manufacturing process.

${ }^{\ddagger}$ United States Pharmacopeia-branded. 
physicians can safely offer patients an alternative therapeutic approach for difficult-to-treat conditions such as hypertriglyceridemia and rheumatoid arthritis. For those without cardiovascular disease, including young mothers and women, it is reasonable to recommend 650 to $1000 \mathrm{mg}$ of low-risk fish oils per day through dietary approaches as suggested by the National Institutes of Health working group, AHA, and the FDA- easily achieved by 1 to 2 fatty fish meals per week.

Understanding the diverse clinical research behind $\Omega-3$ FA can aid family physicians_-adding yet another weapon in their therapeutic arsenal for many diverse clinical conditions. This fish story however, is far from complete. Areas of future research include primary prevention trials, optimal intake of the ratio of $\Omega-6, \Omega-3$, DHA, and EPA, and continued research for various clinical indications. The availability of safe and reliable fish and supplements are paramount in further exploring and unlocking the health benefits of fish.

I thank the faculty development fellowship at Madigan Army Medical Center for their thoughtful and critical review of the manuscript

\section{References}

1. Bang HO, Dyerberg J, Nielsew AB. Plasma lipids and lipoprotein pattern in Greenlandic west-coast Eskimos. Lancet 1971;1:1143-6.

2. Bang HO, Dyerberg J, Sinclair HM. The composition of the Eskimo food in north western Greenland. Am J Clin Nutr 1980;33:2657-61.

3. PubMed [database on the Internet]. Bethesda (MD): National Library of Medicine (US); 2002 [cited 2004 May 11]. Fish oil OR omega-3 OR docosahexaenoic OR eicosapentaenoic, limited to title/abstract [about 499 p.]. Available from: http://www.ncbi.nlm.nih. gov/entrez/query.fcgi.

4. PubMed [database on the Internet]. Bethesda (MD): National Library of Medicine (US); 2002 [cited 2004 May 11]. Fish oil OR omega-3 OR docosahexaenoic OR eicosapentaenoic, limited to title/abstract, human, clinical trials [about52 p.]. Available from: http://www.ncbi.nlm.nih.gov/entrez/query.fcgi.

5. Holub BJ. Clinical nutrition: 4. Omega-3 fatty acids in cardiovascular care. CMAJ 2002;166:608-15.

6. Endres S, Ghorbani R, Kelly VE, et al. The effect of dietary supplementation with n-3 fatty acids on the synthesis of interleukin-1 and tumor necrosis factor by mononuclear cells. N Engl J Med 1989; 320:265-70.

7. Trebble TM, Wootton SA, Miles EA, et al. Prostaglandin $\mathrm{E} 2$ production and $\mathrm{T}$ cell function after fish-oil supplementation: response to antioxidant cosupplementation. Am J Clin Nutr 2003;78:376-82.

8. Leaf A, Kang JX, Xiao YF, Billman GE. Clinical prevention of sudden cardiac death by n-3 polyunsaturated fatty acids and mechanism of prevention of arrhythmias by n-3 fish oils. Circulation 2003;107: 2646-52.

9. Kromhout D, Bosschieter EB, de Lezenne CC. The inverse relation between fish consumption and 20year mortality from coronary heart disease. N Engl J Med 1985;312:1205-9.

10. Daviglus ML, Stamler J, Orencia AJ, et al. Fish consumption and the 30-year risk of fatal myocardial infarction. N Engl J Med 1997;336:1046-53.

11. Hu FB, Bronner L, Willett WC, et al. Fish and omega-3 fatty acid intake and risk of coronary heart disease in women. JAMA 2002;287:1815-21.

12. Albert CM, Hennekens CH, O'Donnell CJ, et al. Fish consumption and risk of sudden cardiac death. JAMA 1998;279:23-8.

13. Albert CM, Campos H, Stampfer MJ, et al. Blood levels of long-chain n-3 fatty acids and the risk of sudden death. N Engl J Med 2002;346:1113-8.

14. Kris-Etherton PM, Harris WS, Appel LJ. AHA scientific statement: fish consumption, fish oil, omega-3 fatty acids, and cardiovascular disease. Circulation 2002;106:2747-57.

15. Singh RB, Niaz MA, Sharma JP, Kumar R, Rastogi V, Moshiri M. Randomized, double-blind, placebocontrolled trial of fish oil and mustard oil in patients with suspected acute myocardial infarction: the Indian experiment of infarct survival-4. Cardiovasc Drugs Ther 1997;11:485-91.

16. Burr ML, Fehily AM, Gilbert JF, et al. Effects of changes in fat, fish and fibre intakes on death and myocardial reinfarction: diet and reinfarction trial (DART). Lancet 1989;2:757-61.

17. Gruppo Italiano per lo Studio della Sopravvivenza nell'Infarto miocardico. Dietary supplementation with n-3 polyunsaturated fatty acids and vitamin $\mathrm{E}$ after myocardial infarction: results of the GISSIPrevenzione trial. Lancet 1999;354:447-55.

18. Marchioli R, Barzi F, Bomba E, et al. Early protection against sudden death by n-3 polyunsaturated fatty acids after myocardial infarction: time-course analysis of the results of the Gruppo Italiano per lo Studio della Sopravvivenza nell'Infarto Miocardico (GISSI)-Prevenzione. Circulation 2002;105:1897-903.

19. Bucher HC, Hengstler P, Schindler C, Meier G. N-3 polyunsaturated fatty acids in coronary heart disease: a meta-analysis of randomized controlled trials. Am J Med 2002;112:298-304.

20. Wang C, Chung M, Lichtenstein A, et al. Effects of omega-3 fatty acids on cardiovascular disease. Evidence report/technology assessment number 94 . AHRQ publication number 04-E009-1. Rockville (MD): Agency for Healthcare Research and Quality; 2004. 
21. National Cholesterol Education Program. Third report of the expert panel on detection, evaluation, and treatment of high blood cholesterol in adults. National Institutes of Health publication no. 02-5215. Bethesda (MD): National Heart, Lung, and Blood Institute; 2002. Available from: http://www.nhlbi.nih. gov/guidelines/cholesterol/index.htm

22. Harris WS. N-3 fatty acids and human lipoprotein metabolism: an update. Lipids 1999;34S:S257-8.

23. Balk E, Chung M, Lichtenstein A, et al. Effects of omega-3 fatty acids on cardiovascular risk factors and intermediate markers of cardiovascular disease. Evidence report/technology assessment no. 93. AHRQ publication no. 04-E010-2. Rockville (MD): Agency for Healthcare Research and Quality; 2004.

24. Phillipson BE, Rothrock DW, Connor WE, Harris WS, Illingworth DR. Reduction of plasma lipids, lipoproteins, and apoproteins by dietary fish oils in patients with hypertriglyceridemia. $\mathrm{N}$ Engl J Med 1985;312:1210-6.

25. Harris WS, Ginsberg HN, Arunakul N, et al. Safety and efficacy of Omacor in severe hypertriglyceridemia. J Cardiovasc Risk 1997;4:385-91.

26. Contacos C, Barter PJ, Sullivan DR. Effect of pravastatin and omega-3 fatty acids on plasma lipids and lipoproteins in patients with combined hyperlipidemia. Arterioscler Thromb 1993;12:1755-62.

27. Durrington PN, Bhatnagar D, Mackness MI, et al. An omega-3 polyunsaturated fatty acid concentrate administered for one year decreased triglycerides in simvastatin treated patients with coronary heart disease and persisting hypertriglyceridemia. Heart 2001;85:544-8.

28. Nordoy A, Hansen JB, Brox J, Svensson B. Effects of atorvastatin and omega-3 fatty acids on LDL subfractions and postprandial hyperlipemia in patients with combined hyperlipemia. Nutr Metab Cardiovasc Dis 2001;11:7-16.

29. Fortin PR, Lew RA, Liang MH, et al. Validation of a meta-analysis: the effects of fish oil in rheumatoid arthritis. J Clin Epidemiol 1995;48:1379-90.

30. MacLean CH, Mojica WA, Morton SC, et al. Effects of omega-3 fatty acids on lipids and glycemic control in type ii diabetes and the metabolic syndrome and on inflammatory bowel disease, rheumatoid arthritis, renal disease, systemic lupus erythematosus, and osteoporosis. Evidence report/technology assessment no. 89. AHRQ publication no. 04-E012-1. Rockville (MD): Agency for Healthcare Research and Quality; 2004.

31. Lau CS, Morley KD, Belch JJ. Effects of fish oil supplementation on non-steroidal anti-inflammatory drug requirement in patients with mild rheumatoid arthritis-a double blind placebo controlled study. Br J Rheumatol 1993;32:982-9.

32. Kremer JM, Lawrence DA, Petrillo GF, et al. Effects of high-dose fish oil on rheumatoid arthritis after stopping nonsteroidal anti-inflammatory drugs. Arthritis Rheum 1995;38:1107-14.

33. Volker D, Fitzgerald P, Major G, Garg M. Efficacy of fish oil concentrate in the treatment of rheumatoid arthritis. J Rheumatol 2000;27:2343-6.

34. Adam O, Beringer C, Kless T, et al. Anti-inflammatory effects of a low arachidonic acid diet and fish oil in patients with rheumatoid arthritis. Rheumatol Int 2003;23:27-36.

35. Kremer JM. N-3 fatty acid supplements in rheumatoid arthritis. Am J Clin Nutr 2000;71:349S-51S.

36. James MJ, Cleland LG. Dietary n-3 fatty acids and therapy for rheumatoid arthritis. Semin Arthritis Rheum 1997;27:85-97.

37. Olsen SF, Secher NJ. Low consumption of seafood in early pregnancy as a risk factor for preterm delivery: prospective cohort study. BMJ 2002;324:1-5.

38. Smuts CM, Huang M, Mundy D, Plasse T, Major S, Carlson SE. A randomized trial of docosahexaenoic acid supplementation during the third trimester of pregnancy. Obstet Gynecol 2003;101:469-79.

39. Olsen SF, Secher NJ, Tabor A, Weber T, Walker JJ, Gluud C. Randomised clinical trials of fish oil supplementation in high risk pregnancies. Fish Oil Trials In Pregnancy (FOTIP) Team. BJOG 2000;107:382-95.

40. SanGiovanni JP, Parra-Cabrera S, Colditz GA, Berkey CS, Dwyer JT. Meta-analysis of dietary essential fatty acids and long-chain polyunsaturated fatty acids as they relate to visual resolution acuity in healthy preterm infants. Pediatrics 2000;105:1292-8.

41. Koo WW. Efficacy and safety of docosahexaenoic acid and arachidonic acid addition to infant formulas: can one buy better vision and intelligence? J Am Coll Nutr 2003;22:101-7.

42. Uauy R, Hoffman DR, Mena P, Llanos A, Birch EE. Term infant studies of DHA and ARA supplementation on neurodevelopment: results of randomized controlled trials. J Pediatr 2003;143:S17-S25.

43. SanGiovanni JP, Berkey CS, Dwyer JT, Colditz GA. Dietary essential fatty acids, long-chain polyunsaturated fatty acids, and visual resolution acuity in healthy fullterm infants: a systematic review. Early Hum Dev 2000;57:165-88.

44. Hoffman DR, Birch EE, Castañeda YS, et al. Visual function in breast-fed term infants weaned to formula with or without long-chain polyunsaturates at 4 to 6 months: a randomized clinical trial. J Pediatr 2003;142:669-77.

45. Helland IB, Smith L, Saarem K, Saugstad OD, Drevon CA. Maternal supplementation with very long chain n-3 fatty acids during pregnancy and lactation augments children's IQ at 4 years of age. Pediatrics 2003;111:E39-E44.

46. Innis SM, Gilley J, Werker J. Are human milk longchain polyunsaturated acids related to visual and neural development in breast-fed term infants? J Pediatr 2001;139:532-8.

47. FDA announces the revised consumer advisory on 
methylmercury in fish. Rockville (MD): Food and Drug Administration; 2004 [cited 2004 May 13]. Available from: http://www.fda.gov/bbs/topics/news/2004/ NEW01038.html

48. Crawford LM. Fish is an important part of a balanced diet [monograph on the Internet]. Rockville (MD): Food and Drug Administration; 2004 [cited 2004 May 13]. Available from: http://www.fda.gov/ oc/opacom/hottopics/mercury/mercuryop-ed.html.

49. Simopoulos AP, Leaf A, Salem N Jr. Workshop statement on the essentiality of and recommended dietary intakes for omega- 6 and omega- 3 fatty acids. Prostaglandins Leukot Essent Fatty Acids 2000;63:119-21.

50. Aslan A, Triadafilopoulos G. Fish oil fatty acid supplementation in active ulcerative colitis: a double blind, placebo-controlled, crossover study. Am J Gastroenterol 1992;87:432-7.

51. Belluzzi A, Brignola C, Campieri M, Pera A, Boschi S, Miglioli M. Effect of an enteric-coated fish-oil preparation on relapses in Crohn's disease. N Engl J Med 1996;334:1557-60.

52. Belluzzi A, Boschi S, Brignola C, Munarini A, Cariani G, Miglio F. Polyunsaturated fatty acids and inflammatory bowel disease. Am J Clin Nutr 2000; 71S:339S-42S.

53. Woods RK, Thien FC, Abramson MJ. Dietary marine fatty acids (fish oil) for asthma in adults and children. Cochrane Database Syst Rev 2002;(3): CD001283.

54. Schachter H, Reisman J, Tran K, et al. Health effects of omega-3 fatty acids on asthma. Evidence report/ technology assessment no. 91. AHRQ publication no. 04-E013-2. Rockville (MD): Agency for Healthcare Research and Quality; 2004.

55. Van Gool CJ, Zeegers MP, Thijs C. Oral essential fatty acid supplementation in atopic dermatitis-a meta-analysis of placebo-controlled trials. Br J Dermatol 2004;150:728-40.

56. Soyland E, Funk J, Rajka G, Sandberg M, Thune P, Rustad L, et al. Effect of dietary supplementation with very-long-chain $n-3$ fatty acids in patients with psoriasis. N Engl J Med 1993;328:1812-6.

57. Mayser P, Mrowietz U, Arenberger P, et al. Omega-3 fatty acid-based lipid infusion in patients with chronic plaque psoriasis: results of a double-blind, randomized, placebo-controlled, multicenter trial. J Am Acad Dermatol 1998;38:539-47.

58. Donadio JV Jr, Grande JP, Bergstralh EJ, Dart RA, Larson TS, Spencer DC. The long-term outcome of patients with IgA nephropathy treated with fish oil in a controlled trial. Mayo Nephrology Collaborative Group. J Am Soc Nephrol 1999;10:1772-7.

59. Strippoli GF, Manno C, Schena FP. An "evidencebased" survey of therapeutic options for IgA nephropathy: assessment and criticism. Am J Kidney Dis 2003;41:1129-39.

60. Stoll AL, Severus WE, Freeman MP, et al. Omega-3 fatty acids in bipolar disorder: a preliminary doubleblind, placebo-controlled trial. Arch Gen Psychiatry 1999;56:407-12.

61. Su KP, Huang SY, Chiu CC, Shen WW. Omega-3 fatty acids in major depressive disorder. A preliminary double-blind placebo-controlled trial. Eur Neuropsychopharmacol 2003;13:267-71.

62. Iso H, Rexrode KM, Stampfer MJ, et al. Intake of fish and omega- 3 fatty acids and risk of stroke in women. JAMA 2001;285:304-12.

63. He K, Rimm EB, Merchant A, et al. Fish consumption and risk of stroke in men. JAMA 2002;288:3130-6.

64. Morris MC, Evans DA, Bienias JL, et al. Consumption of fish and n-3 fatty acids and risk of incident Alzheimer disease. Arch Neurol 2003;60:940-6.

65. Hites RA, Foran JA, Carpenter DO, Hamilton MC, Knuth BA, Schwager SJ. Global assessment of organic contaminants in farmed salmon. Science 2004; 303:226-9.

66. Advice on fish consumption: benefits and risks [monograph on the internet]. London: United Kingdom Food Standards Agency; 2004 [cited 2004 Jul 20] Available from: http://www.food.gov.uk/news/ newsarchive/2004/jun/fishreport2004.

67. Guideline for assessing chemical contaminant data for use in fish advisories. Volume 2: risk assessment and fish consumption limits, 3rd ed. Washington DC: Environmental Protection Agency; [cited 2004 May 13]. Available from: http://www.epa.gov/water science/fishadvice/volume2/index.html.

68. Randomized trial of cholesterol lowering in 4444 patients with coronary heart disease: the Scandinavian Simvastatin Survival Study (4S). Lancet 1994; 344:1383-9.

69. Sacks FM, Pfeffer MA, Moye L, et al. The effect of pravastatin on coronary events after myocardial infarction in patients with average cholesterol levels. Cholesterol and Recurrent Events Trial Investigators. N Engl J Med 1996;335:1001-9.

70. Guallar E, Sanz-Gallardo MI, van't Veer P, et al. Mercury, fish oils, and the risk of myocardial infarction. N Engl J Med 2003;347:1747-54.

71. Yoshizawa K, Rimm EB, Morris JS, et al. Mercury and the risk of coronary heart disease in men. N Engl J Med 2002;347:1755-60.

72. Substances affirmed as generally recognized as safe: menhaden oil, 21 C.F.R. Sect. 184.1472 (2001).

73. Conner WE. Fish oil in hypertriglyceridemia: safety and recommendations [abstract]. Lipids 1999;34S:271.

74. Montori VM, Farmer A, Wollan P, Dinneen SF. Fish oil supplementation in type 2 diabetes: a quantitative systematic review. Diabetes Care 2000;23:1407-15.

75. Foran SE, Flood JG. Lewandrowski KB. Measurement of mercury levels in concentrated over-thecounter fish oil preparations. Arch Pathol Lab Med 2003;127:1603-5. 